\title{
A high density genetic map of maritime pine based on AFLPs
}

\author{
David Chagné ${ }^{\mathrm{a}}$, Céline Lalanne ${ }^{\mathrm{a}}$, Delphine Madur ${ }^{\mathrm{a}}$, Satish Kumar ${ }^{\mathrm{b}}$, Jean-Marc Frigério ${ }^{\mathrm{a}}$, \\ Catherine Krier ${ }^{\mathrm{a}}$, Stéphane Decroocq ${ }^{\mathrm{a}}$, Arnould Savouréc, Magida Bou-Dagher-Kharrat ${ }^{\mathrm{c}}$, \\ Evangelista Bertocchi ${ }^{\mathrm{a}}$, Jean Brach ${ }^{\mathrm{a}}$ and Christophe Plomion ${ }^{\mathrm{a}^{*}}$
}

\author{
a INRA, Équipe de Génétique et Amélioration des Arbres Forestiers, 69 route d'Arcachon, 33612 Cestas Cedex, France \\ ${ }^{b}$ Forest Research, Applications of Genomic Science, Sala Street, Rotorua, 3021, New Zealand \\ ${ }^{c}$ Physiologie Cellulaire et Moléculaire des Plantes, UMR 7632 CNRS, Université Pierre et Marie Curie, case 156, \\ 4 Place Jussieu, 75252 Paris Cedex 05, France
}

(Received 16 August 2001; accepted 13 February 2002)

\begin{abstract}
We constructed a high-density linkage map of maritime pine (Pinus pinaster Ait.) based on AFLP (Amplified Fragment Length Polymorphism) markers using a three-generation outbred pedigree. In a first step, male and female maps were established independently with test-cross markers segregating 1:1 (presence:absence of the amplified fragment in the full-sib progeny). In a second step, both maps were merged using intercross markers segregating 3:1 in the progeny. A combination of MAPMAKER and JOINMAP softwares was used for the mapping process. A consensus map was obtained and is available at URL http://www.pierroton.inra.fr/genetics/pinus/Map3/index.html. It covers $1441 \mathrm{cM}$ and comprises a total of 620 AFLP markers on 12 linkage groups. The physical size of the maritime pine genome (51.5 pg/2C) was measured by flow cytometry, providing a physical/genetic size ratio of $13.78 \mathrm{Mb} / \mathrm{cM}$. This map will be used to dissect the genetic architecture of economically (growth, wood quality) and ecologically (water-use efficiency) important traits into mendelian inherited components (QTLs: Quantitative Trait Loci). It will also provide a framework to localize more informative markers (ESTs: Expressed Sequence Tags) to be used as candidate genes in QTL detection experiments. The location of orthologous markers (ESTs and SSRs: Simple Sequence Repeats) will also allow the study of the genome structure of closely related conifer species using a comparative genome mapping approach.
\end{abstract}

Pinus pinaster / genetic linkage map / AFLP / double pseudo-testcross / physical size

Résumé - Établissement d'une carte génétique à haute densité du pin maritime à partir de marqueurs AFLP. Nous avons construit une carte génétique du pin maritime (Pinus pinaster Ait.) en génotypant une famille de plein-frères appartenant à la troisième génération du programme d'amélioration, avec des marqueurs AFLP. Dans un premier temps, les cartes des parents mâle et femelle ont été établies indépendamment avec des marqueurs de type «test-cross » ségréguant dans les proportions 1:1 (présence:absence du fragment amplifié dans la famille de plein-frères). Dans un second temps ces deux cartes ont été fusionnées à l'aide de marqueurs de type « intercross », ségréguant dans les proportions 3:1. La construction des cartes a été réalisée à l'aide des logiciels de cartographie génétique JOINMAP et MAPMAKER. Une carte génétique consensus des deux parents comprenant 12 groupes de liaison a finalement été obtenue et est accessible à l'URL suivante : http://www.pierroton.inra.fr/genetics/pinus/Map3/index.html. Elle couvre $1441 \mathrm{cM}$ et comprend 620 marqueurs. Par ailleurs, la taille physique du génome du pin maritime a été estimée par cytométrie de flux à $51.5 \mathrm{pg} / 2 \mathrm{C}$, donnant un rapport taille physique/taille génétique de 13.78 $\mathrm{Mb} / \mathrm{cM}$. Cette carte sera maintenant utilisée pour étudier l'architecture génétique de caractères d'intérêt économique (croissance, qualité du bois) et écologique (efficience d'utilisation de l'eau). Il s'agira de localiser les zones du génome (QTL, Quantitative Trait Loci) impliquées dans le contrôle génétique de ces caractères complexes. La carte génétique fournira aussi un support pour localiser d'autres types de marqueurs, tels que des gènes (EST, Expressed Sequence Tags) qui seront utilisés comme marqueurs candidats pouvant correspondre aux QTL. La localisation de marqueurs orthologues (EST et SSR, Simple Sequence Repeats) permettra d'étudier en outre la structure du génome des conifères en utilisant une approche par cartographie comparée.

pin maritime / carte génétique / AFLP / double pseudo-testcross / taille physique

\footnotetext{
* Correspondence and reprints

Tel.: +33 5571228 38; fax: +33 5571228 81; e-mail: plomion@ pierroton.inra.fr
} 


\section{INTRODUCTION}

Maritime pine (Pinus pinaster Ait.) is the most economically and ecologically important conifer species in the southwestern Europe, where it covers about 4 millions hectares. In France, INRA (Institut National de la Recherche Agronomique) started a breeding programme of maritime pine in the early sixties to provide foresters with improved varieties for growth and straightness. This program has now reached its third generation. Although positive genetic gains are obtained through classical breeding strategies [5], there is a great need to improve selection efficiency. Indeed, forest tree selection faces three major stumbling blocks: (i) late selection age (12 years of age for maritime pine, [32]), (ii) complex traits with low to medium heritabilities [17,31, 48], (iii) and late flowering ( 8 years of age for maritime pine). The development of molecular marker techniques provides new tools to detect the genomic regions involved in the genetic control of quantitative traits (QTLs, Quantitative Trait Loci, [59]), which, in turn, will improve selection efficiency and will increase genetic gains per unit of time. A prerequisite of this strategy is the availability of a saturated genetic linkage map for the studied species.

Previous reviews have described the specificity of the different mapping strategies used in forest trees [14, 42]. A comprehensive review of inheritance and mapping studies in conifers, indicating the type of pedigree and marker techniques used, is also available at: http: //www.pierroton.inra.fr/genetics/labo/mapreview.html. Chronologically, inheritance and mapping studies were performed using the megagametophyte, a nutritive haploid tissue surrounding the embryo of gymnosperm seeds and corresponding to the female inheritance transmitted to the embryo [63]. Markers used by the forest tree geneticists in the 70's and 80's were isozymes [1]. However, a large proportion of the genome could not be covered by a too few number of loci. The use of this haploid tissue climaxed in the mid-90's, when randomly amplified polymorphic DNA (RAPD, [68]) became the most popular marker technique to produce genetic maps for plant species. In particular, the haploid megagametophyte of conifer seeds avoided the drawback of the dominant nature of RAPDs. The "megagametophyte-RAPD" strategy was used in several conifer species, including $P$. pinaster [44], from which the first conifer saturated map was published. In the late 90's, RAPDs were progressively abandoned with the availability of a more reliable technique: Amplified Fragment Length Polymorphism (AFLP, [66]), which was used in several conifer species such as pinyon pine [62], loblolly pine [51] and maritime pine $[18,53]$. Although very popular in the forest geneticist community, the megagametophyte approach faces two major limitations. First, it requires the development of specific populations and is not applicable to QTL analysis for mature traits in existing plantations. Indeed, the megagametophyte is a temporary tissue that can only be collected from the seedling stage during the germination of the embryo. Therefore, the dissection of the genetic architecture of adult trait would require several years to start. In addition, only the maternal effect of QTL can be estimated [45, 46]. Second, the haploid progeny cannot be considered as a "perpetual" mapping population, because of the relatively low amount of DNA that can be extracted from this tissue. Consequently, it will prevent a high number of markers, as well as markers requiring a high amount of DNA such as RFLPs (Restriction Fragment Length Polymorphisms, [8]), from being mapped over time.

Conversely, adult trees can be grafted and propagated by cuttings, and diploid progenies can constitute "perpetual" population, analogous to Recombinant Inbred Lines in crop plants. Carlson et al. [11] were the first to show that RAPD primers could be screened for informative markers segregating in a 1:1 ratio in diploid tissue of full-sib progenies. This idea was extended by Grattapaglia and Sederoff [24] to construct parental maps of an interspecific eucalyptus hybrid family, in a mapping strategy named "two-way pseudotestcross". It was further used in conifers $[3,33]$ with RAPDs and AFLPs.

Although dominant biallelic markers (RAPD and AFLP) continue to be the most easy-to-use technique, they present major limitation since they cannot capture the multiallelic nature of QTLs. Alternatively, other research groups started to use codominant markers such as RFLPs [10, 19, 54], PCR-RFLP [26], ESTs (Expressed Sequence Tags) [12, 47, 61] and more recently SSRs (Simple Sequence Repeats) [19, $22,43]$, allowing gene action to be precisely defined (estimation of additive and dominant effects of QTLs, [55]) and providing anchor points in comparative mapping experiments [39].

This brief review of the history of molecular marker development can give us insights on how to proceed in the development of a molecular genetics project in maritime pine. In a first step we identified a three-generation outbred pedigree comprising 202 individuals and segregating for traits of interest. Second, we quickly established a fully saturated map based on AFLP markers. Third, we are now mapping QTL for traits of interest and developing SSRs and ESTPs (EST Polymorphisms) to provide more informative markers which should be easily transferred to other pedigrees of maritime pine and other pine species, with the main objective of QTL validation [39]. The main goal of this paper is to present a saturated map of maritime pine which corresponds to the second step of this strategy.

\section{MATERIALS AND METHODS}

\subsection{Mapping population}

A three-generation outbred pedigree $(9.103 .3 \times 10.159 .3)$ was used to construct the genetic map (figure 1). The two parental trees were mated in 1980 and seeds from the controlled cross were sown in spring 1982. They produced 202 progeny seedlings that were 


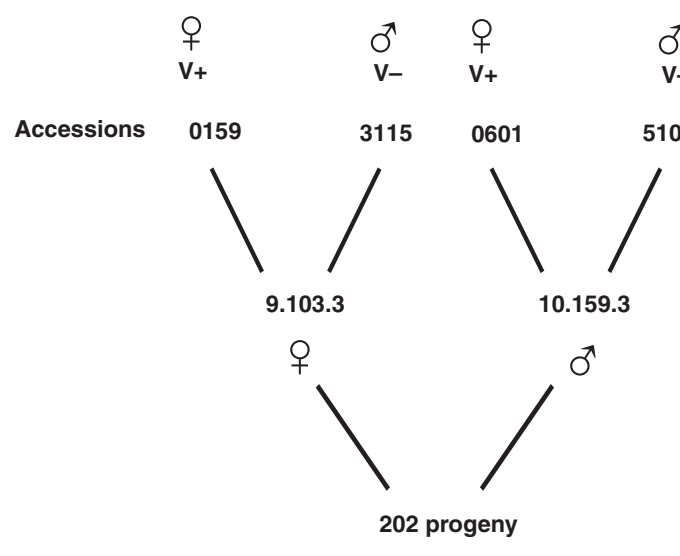

Figure 1. Mapping pedigree: 202 full-sibs belonging to the third generation of the maritime pine breeding programme ( $\mathrm{V}+$ : vigorous trees, $\mathrm{V}-$ : less vigorous trees).

planted in autumn 1982. The four grand parents were "plus trees" phenotypically selected for stem growth and straightness in the local provenance of the Landes de Gascogne, and grafted in clonal orchards. These grand parents were tested in a polycross progeny test and classified according to their breeding value as Vigor "+" (for vigorous trees) and Vigor "-_" (for less vigorous trees). The progeny was located in Malente (Gironde, France) on a semi-humid podzolic soil. Spacing was $4 \mathrm{~m}$ between rows and $1.1 \mathrm{~m}$ between individual trees, i.e. 2272 trees ha $^{-1}$. This full-sib family belongs to a progeny test of the third generation breeding population.

\subsection{AFLP assay and gel electrophoresis}

Genomic DNA was extracted as described by Doyle and Doyle [21]. AFLP markers were obtained following the protocol of Costa et al. [18] with slight modifications: the EcoRI primers used for selective amplification were radio labelled for $1.0 \mathrm{~h}$ at $37{ }^{\circ} \mathrm{C}$ in $1 \times$ OPA buffer (Pharmacia), $9.5 \mathrm{U}$ of T4 kinase (Pharmacia), $100 \mu \mathrm{M}$ of primer and $10 \mu \mathrm{Ci}$ of $\gamma^{33} \mathrm{P}-\mathrm{ATP}$. The reaction was stopped by incubating the reaction mix for $10 \mathrm{~min}$ at $80{ }^{\circ} \mathrm{C}$. After selective amplification, $4 \mu \mathrm{l}$ of denaturated template was loaded, after one hour of pre-run, on to $52 \mathrm{~cm}$ gels composed of 4\% 19:1 acrylamide: bis-acrylamide, $7 \mathrm{M}$ urea and $1 \times \mathrm{TBE}$. The run was performed at $80 \mathrm{~W}$ for $150 \mathrm{~min}$ or more, depending on the primer combination. The gel was fixed after running in $10 \%$ acetic acid for $20 \mathrm{~min}$, rinsed in distilled water and dried overnight at $50{ }^{\circ} \mathrm{C}$. Finally, gels were exposed on Konica AX autoradiographic film for about 8 days.

Fifty-two primer-enzyme combinations (PEC, see table I) were chosen on the basis of their repeatability, pattern (i.e. ease of scoring) and level of polymorphism. Presence or absence of AFLP fragments was directly scored on the gel image (figure 2).

Polymorphic AFLP fragments were named considering (1) the PEC used; (2) the fragment length, and (3) the quality of the scoring: "a" for intense bands, "b" for weak bands, and "c" for the bands that were difficult to score. A table of correspondence between the locus ID and the PEC used is available online at URL: http://www.pierroton.inra.fr/genetics/pinus/Map3/marker_table.html.

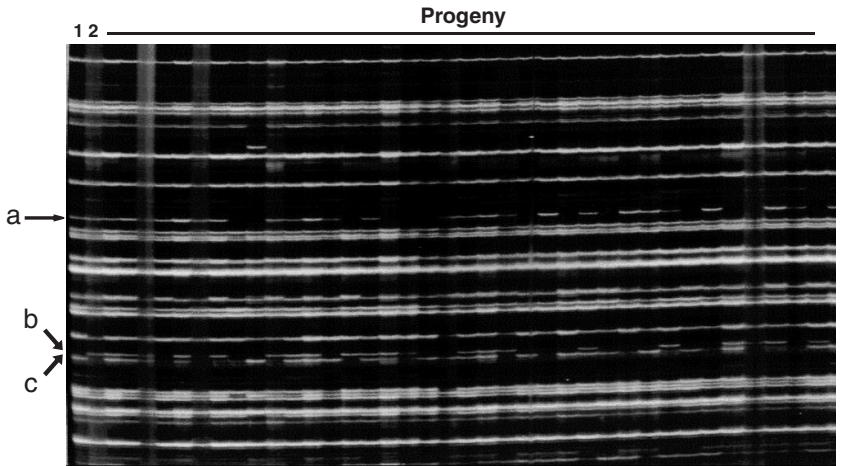

Figure 2. Example of AFLP profile showing the three types of segregation. Lanes 1 and 2 correspond to the parents (female and male) and other lanes correspond to the full-sib progeny. (A) Inter-cross marker, heterozygous in both parents and segregating 3:1 in the progeny; (B) Test-cross marker, heterozygous in the male and absent in the female, and segregating 1:1 in the progeny; (C) Test-cross marker, heterozygous in the female and absent in the male, and segregating 1:1 in the progeny.

\subsection{Mapping procedure}

We used the two-way pseudo-test cross mapping strategy to construct the linkage maps [24]. Markers were subdivided into two groups considering their segregation patterns. The first group comprised markers in the testcross configuration between the parents (heterozygous in one parent and homozygous null in the other), which presented a 1:1 segregation ratio in the progeny. The second group concerned markers heterozygous in both parents, and therefore segregating in a 3:1 ratio in the progeny. Mendelian segregation of the markers was tested by chi-square tests $(P>0.01)$. The few distorted 1:1 and 3:1 markers were discarded from further analysis. They generally belonged to the "c" quality score category.

Because of the low information content between pairs of markers segregating in the $1: 1$ and $3: 1$ configuration [52], a preliminary grouping of the 1:1 markers only was performed for each parent using MAPMAKER software [34] with a LOD threshold of 6. Our objective was to construct precise parental maps with 1:1 markers to compare with the results obtained later with JOINMAP. The two parental maps based on $1: 1$ and $3: 1$ markers were built using JOINMAP v1.4 software [57] with a minimum LOD of 3 used as grouping criterion and then aligned based on 3:1 markers. Whenever the ordering of 3:1 markers was disturbed, the corresponding markers were discarded until a good ordering was obtained. A consensus map was finally built using all 1:1 and selected 3:1 markers using JOINMAP. Linkage groups were drawn using MAPCHART [65]. Recombination rates were converted to map distances in centiMorgans (cM) using the Kosambi mapping function.

\subsection{Physical size measurement}

DNA content of embryos or megagametophytes was assessed by flow cytometry. Ten seeds were first imbibed overnight and then dissected to separate the megagametophyte from the embryo. Triticum aestivum $(2 \mathrm{C}=30.9 \mathrm{pg}$, [35]) was used as an internal standard. Pinus tissues and hexaploid wheat leaf were chopped together with a razor blade in Galbraith buffer [23] slightly modified by the addition of $10 \mathrm{mM}$ metabisulfite, $1 \%$ (w/v), Triton X-100 and 
Table I. List of AFLP primer pairs used to construct the maritime pine genetic map and number of polymorphic fragments.

\begin{tabular}{|c|c|c|c|c|}
\hline PEC & \multirow{2}{*}{$\begin{array}{c}\begin{array}{c}\text { Number of } \\
\text { amplified } \\
\text { fragments }\end{array} \\
140\end{array}$} & \multirow{2}{*}{$\begin{array}{c}\text { Number of } \\
\text { markers se- } \\
\text { gregating 1:1 } \\
(1) \\
10\end{array}$} & \multirow{2}{*}{$\begin{array}{c}\text { Number of } \\
\text { markers se- } \\
\text { gregating 3:1 } \\
\text { (2) } \\
7\end{array}$} & \multirow{2}{*}{$\begin{array}{r}\text { Total } \\
(1)+(2) \\
\\
17\end{array}$} \\
\hline $1 \mathrm{E}+\mathrm{ACA} / \mathrm{M}+\mathrm{CCAG}$ & & & & \\
\hline $2 \mathrm{E}+\mathrm{ACA} / \mathrm{M}+\mathrm{CCGA}$ & 130 & 9 & 7 & 16 \\
\hline $3 \mathrm{E}+\mathrm{ACG} / \mathrm{M}+\mathrm{CCGC}$ & 108 & 8 & 1 & 9 \\
\hline $4 \mathrm{E}+\mathrm{ACG} / \mathrm{M}+\mathrm{CCAG}$ & 60 & 9 & 5 & 14 \\
\hline $5 \mathrm{E}+\mathrm{ACG} / \mathrm{M}+\mathrm{CCGT}$ & 95 & 10 & 1 & 11 \\
\hline 6 E+ACG/M+CCTA & 56 & 4 & 4 & 8 \\
\hline 7 E+ACG/M+CCCA & 112 & 5 & 3 & 8 \\
\hline $8 \mathrm{E}+\mathrm{ACG} / \mathrm{M}+\mathrm{CCAA}$ & 118 & 12 & 1 & 13 \\
\hline 9 E+ACG/M+CCTG & 62 & 26 & 3 & 29 \\
\hline $10 \mathrm{E}+\mathrm{ACC} / \mathrm{M}+\mathrm{CCAG}$ & 140 & 13 & 5 & 18 \\
\hline $11 \mathrm{E}+\mathrm{ACC} / \mathrm{M}+\mathrm{CCTG}$ & 126 & 9 & 5 & 14 \\
\hline $12 \mathrm{E}+\mathrm{ACC} / \mathrm{M}+\mathrm{CCGT}$ & 70 & 7 & 1 & 8 \\
\hline $13 \mathrm{E}+\mathrm{ACC} / \mathrm{M}+\mathrm{CCTA}$ & 145 & 10 & 4 & 14 \\
\hline $14 \mathrm{E}+\mathrm{ACC} / \mathrm{M}+\mathrm{CCGA}$ & 110 & 8 & 2 & 10 \\
\hline $15 \mathrm{E}+\mathrm{ACT} / \mathrm{M}+\mathrm{CCGC}$ & 130 & 9 & 2 & 11 \\
\hline $16 \mathrm{E}+\mathrm{ACT} / \mathrm{M}+\mathrm{CCAG}$ & 110 & 11 & 1 & 12 \\
\hline $17 \mathrm{E}+\mathrm{ACT} / \mathrm{M}+\mathrm{CCTG}$ & 120 & 14 & 7 & 21 \\
\hline $18 \mathrm{E}+\mathrm{ACT} / \mathrm{M}+\mathrm{CCGT}$ & 130 & 7 & 5 & 12 \\
\hline $19 \mathrm{E}+\mathrm{ACT} / \mathrm{M}+\mathrm{CCCA}$ & 136 & 4 & 4 & 8 \\
\hline $20 \mathrm{E}+\mathrm{ACT} / \mathrm{M}+\mathrm{CCTA}$ & 105 & 9 & 6 & 15 \\
\hline $21 \mathrm{E}+\mathrm{ACAA} / \mathrm{M}+\mathrm{CCTA}$ & 95 & 6 & 9 & 15 \\
\hline $22 \mathrm{E}+\mathrm{ACAA} / \mathrm{M}+\mathrm{CCAC}$ & 100 & 6 & 5 & 11 \\
\hline $23 \mathrm{E}+\mathrm{ACAA} / \mathrm{M}+\mathrm{CCGC}$ & 140 & 9 & 3 & 12 \\
\hline $24 \mathrm{E}+\mathrm{ACAA} / \mathrm{M}+\mathrm{CCCA}$ & 140 & 12 & 5 & 17 \\
\hline $25 \mathrm{E}+\mathrm{ACAA} / \mathrm{M}+\mathrm{CCGA}$ & 110 & 4 & 5 & 9 \\
\hline $26 \mathrm{E}+\mathrm{ACAA} / \mathrm{M}+\mathrm{CCTT}$ & 136 & 17 & 4 & 21 \\
\hline $27 \mathrm{E}+\mathrm{ACAA} / \mathrm{M}+\mathrm{CCTG}$ & 70 & 9 & 4 & 13 \\
\hline $28 \mathrm{E}+\mathrm{ACAA} / \mathrm{M}+\mathrm{CCAG}$ & 75 & 10 & 4 & 14 \\
\hline $29 \mathrm{E}+\mathrm{ACAA} / \mathrm{M}+\mathrm{CCAT}$ & 110 & 12 & 4 & 16 \\
\hline $30 \mathrm{E}+\mathrm{ACAC} / \mathrm{M}+\mathrm{CCAA}$ & 100 & 9 & 2 & 11 \\
\hline $31 \mathrm{E}+\mathrm{ACAC} / \mathrm{M}+\mathrm{CCAT}$ & 130 & 16 & 10 & 26 \\
\hline $32 \mathrm{E}+\mathrm{ACAC} / \mathrm{M}+\mathrm{CCTA}$ & 100 & 7 & 2 & 9 \\
\hline $33 \mathrm{E}+\mathrm{ACAC} / \mathrm{M}+\mathrm{CCTT}$ & 100 & 12 & 8 & 20 \\
\hline $34 \mathrm{E}+\mathrm{ACAC} / \mathrm{M}+\mathrm{CCTC}$ & 90 & 9 & 3 & 12 \\
\hline $35 \mathrm{E}+\mathrm{ACAC} / \mathrm{M}+\mathrm{CCAG}$ & 123 & 9 & 3 & 12 \\
\hline $36 \mathrm{E}+\mathrm{ACAC} / \mathrm{M}+\mathrm{CCAC}$ & 100 & 13 & 4 & 17 \\
\hline $37 \mathrm{E}+\mathrm{ACAG} / \mathrm{M}+\mathrm{CCTG}$ & 114 & 15 & 4 & 19 \\
\hline $38 \mathrm{E}+\mathrm{ACAG} / \mathrm{M}+\mathrm{CCTA}$ & 107 & 9 & 3 & 12 \\
\hline $39 \mathrm{E}+\mathrm{ACAG} / \mathrm{M}+\mathrm{CCAT}$ & 104 & 18 & 9 & 27 \\
\hline $40 \mathrm{E}+\mathrm{ACAG} / \mathrm{M}+\mathrm{CCAA}$ & 99 & 14 & 3 & 17 \\
\hline $41 \mathrm{E}+\mathrm{ACAG} / \mathrm{M}+\mathrm{CCGA}$ & 120 & 6 & 6 & 12 \\
\hline $42 \mathrm{E}+\mathrm{ACAG} / \mathrm{M}+\mathrm{CCTC}$ & 110 & 5 & 7 & 12 \\
\hline $43 \mathrm{E}+\mathrm{ACAG} / \mathrm{M}+\mathrm{CCGT}$ & 130 & 3 & 6 & 9 \\
\hline $44 \mathrm{E}+\mathrm{ACAG} / \mathrm{M}+\mathrm{CCGC}$ & 145 & 9 & 5 & 14 \\
\hline $45 \mathrm{E}+\mathrm{ACAT} / \mathrm{M}+\mathrm{CCAG}$ & 115 & 10 & 7 & 17 \\
\hline $46 \mathrm{E}+\mathrm{ACAT} / \mathrm{M}+\mathrm{CCTA}$ & 110 & 15 & 9 & 24 \\
\hline $47 \mathrm{E}+\mathrm{ACAT} / \mathrm{M}+\mathrm{CCAT}$ & 132 & 7 & 6 & 13 \\
\hline $48 \mathrm{E}+\mathrm{ACAT} / \mathrm{M}+\mathrm{CCTC}$ & 143 & 20 & 9 & 29 \\
\hline $49 \mathrm{E}+\mathrm{ACAT} / \mathrm{M}+\mathrm{CCTG}$ & 105 & 2 & 6 & 8 \\
\hline $50 \mathrm{E}+\mathrm{ACAT} / \mathrm{M}+\mathrm{CCAC}$ & 138 & 13 & 9 & 22 \\
\hline $51 \mathrm{E}+\mathrm{ACAT} / \mathrm{M}+\mathrm{CCCA}$ & 145 & 6 & 8 & 14 \\
\hline $52 \mathrm{E}+\mathrm{ACAT} / \mathrm{M}+\mathrm{CCGA}$ & 115 & 7 & 7 & 14 \\
\hline TOTAL & 5854 & 513 & 253 & 766 \\
\hline
\end{tabular}

$1 \%$ (w/v) polyethylene glycol (PEG) 8000. After addition of 5 units $\mathrm{mL}^{-1}$ RNase A (Roche, France) and $50 \mu \mathrm{g} \mathrm{mL}^{-1}$ propidium iodide (Sigma-Aldrich, France), nuclei were filtered through a $75 \mu \mathrm{m}$ nylon filter in order to eliminate cell debris. Samples were left $30 \mathrm{~min}$ on ice before measurements.

Assuming a linear relationship between fluorescence ratio and amount of DNA, total 2C DNA content was evaluated using the leaf $2 \mathrm{C}$ DNA value of hexaploid wheat. For each sample, measurements were made on 2500 nuclei with duplication. Fluorescence analysis of the stained nuclei was performed on an Epics $\mathrm{V}$ cytometer (Beckman-Coulter, Roissy, France) with an argon laser at $488 \mathrm{~nm}$ for propidium iodide. The cytometer linearity was checked and adjusted before each set of run.

\section{RESULTS AND DISCUSSION}

\subsection{AFLP markers}

The 52 PECs used in this study provided 766 non-distorted AFLP markers. The number of polymorphic fragments ranged from 8 to 29 with an average of 15 polymorphic markers per combination. $253(33 \%)$ markers segregated in the $3: 1$ ratio and $513(66 \%)$ in the $1: 1$ ratio. A total of $251(32.8 \%)$ of these 513 markers were heterozygous for the male parent and $262(34.2 \%)$ for the female parent.

In a short time, and for a rather low cost, the AFLP method provided a sufficient amount of polymorphic markers to saturate the genome of maritime pine. In spite of its large genome size, the use of appropriate PECs allowed the production of easy-to-score AFLP gels. The use of Pst-Mse PECs has been reported to provide less complex gel patterns but also yields non-randomly distributed markers in conifers [43]. PstI is sensitive to methylation and the use of this endonuclease may target low-copy clustered regions. To avoid this problem and ensure full genome coverage, we used Eco-Mse PECs. By using two selective nucleotides in the pre-amplification step $(E c o R I+2, M s e I+2)$, and three to four nucleotides in the selective amplification step (EcoRI $+3 /+4 M s e I+4)$, we could circumvent the complexity of the pine genome to produce clear AFLP patterns $[15,25]$.

Remington et al. [51] reported a significant effect of the composition of the selective extensions. They showed that the amount of $\mathrm{CpG}$ was negatively correlated with the number of polymorphic fragments. In this study, although a slight decrease was also observed, an analysis of variance (not shown) test showed that there were no significant relationship between the number of polymorphic bands and the $\mathrm{CpG}$ content in both EcoRI and MseI primers $(P$-value $=0.21)$.

\subsection{Linkage map}

Some polymorphic markers were discarded from the linkage analysis because they were distorted $(P<0.01)$. It should be noticed that the observed level of distorsion was not significantly greater than that expected by chance alone. In 
respect to the $3: 1$ markers, only a subset (42\%) that showed the same order in the parental maps were kept. Six hundred and twenty markers were finally used to construct the consensus linkage map (figure 3). The map consisted of 12 linkage groups, corresponding to the 12 haploid chromosomes of $P$. pinaster.

The total lengths obtained for the female, the male and the consensus maps using JOINMAP and MAPMAKER softwares are presented in table II. The total genetic length calculated using MAPMAKER software on the female map $(1807 \mathrm{cM})$ is not significantly different from those described by Plomion et al. [44] and Costa et al. [18] on the same species (1 $860 \mathrm{cM}$ and $1873 \mathrm{cM}$, respectively). On the other hand, the comparison between the total genetic lengths obtained with JOINMAP or MAPMAKER are different, even if the same mapping function (Kosambi) was used in both software. Qi et al. [49] in barley and Sewell et al. [54] in loblolly pine reported the same phenomenon, which can be attributed to how the software packages calculate the genetic distances: in any case the assumed level of interference differs slightly from the true interference.

\subsection{Physical versus genetic size}

Improvements of the extraction buffer allowed analysis of fair quality with a highly reproducible fluorescence index $\left(2 \mathrm{C}_{\text {Pinus }} / 2 \mathrm{C}_{\text {standard }}\right)$. Analysis of $P$. pinaster embryo tissues yielded DNA histograms with coefficients of variation in the $2 \mathrm{C}$ peaks ranging from 2 to $4 \%$. Hexaploid wheat was used as an internal standard because its genome size is relatively high and thus more convenient in the assessment of large genome. The mean DNA value (2C) for $P$. pinaster was $51.49 \pm 0.51 \mathrm{pg}$. The ratio between the fluorescence peak of nuclei isolated
Table II. Total genetic lengths and number of linkage group (LG) obtained for female, male and consensus maps using two different mapping softwares.

\begin{tabular}{lcc}
\hline & JOINMAP & MAPMAKER \\
\hline Female & $1218 \mathrm{cM}(12 \mathrm{LG})$ & $1807 \mathrm{cM}(12 \mathrm{LG})$ \\
Male & $1297 \mathrm{cM}(15 \mathrm{LG})$ & $1541 \mathrm{cM}(16 \mathrm{LG})$ \\
Consensus & $1407 \mathrm{cM}(12 \mathrm{LG})$ & - \\
\hline
\end{tabular}

from the diploid $P$. pinaster embryos and the corresponding megagametophyte haploid tissue was equal to 1.92 .

The Pinaceae presents the widest range and diversity of DNA contents in all gymnosperm families [30, 37, 40, 41]. $P$. pinaster, with a $2 \mathrm{C}$ DNA value of $51.49 \mathrm{pg} / 2 \mathrm{C}\left(25.7 \times 10^{9}\right.$ base pair per 1C) is close to most of the Pinus species. The highest DNA reported in Pinus genus and also in gymnosperm is $63.5 \mathrm{pg} / 2 \mathrm{C}$ in Pinus lambertiana [37]. For the moment, it is not clear if the large diversity of the Pinus genome sizes procures an advantage to environmental conditions as hypothesised by Wakamiya et al. [67].

Table III compares the genetic and physical size of maritime pine and several other plant genome, including forest trees belonging to angiosperms (oak [6], poplar [16], eucalyptus [36]) and gymnosperms (Loblolly pine [54]). The two pine species show higher physical lengths compared to the other species, which translates into a much larger physi cal/genetic size ratio (e.g.: $13.78 \mathrm{Mbp} / \mathrm{cM}$ in $P$. pinaster versus $0.22 \mathrm{Mbp} / \mathrm{cM}$ in Arabidopsis thaliana). Figure 4 shows the relationship between the number of crossing-over and the mean physical size of a chromosome. The number of crossing-over is highly negatively correlated with chromosome size $(\mathrm{R}=-0.88, P<0.01)$. As the number of crossing-over occurring during the meiosis does not differ strongly between

Table III. Genome characteristics of 15 plant species.

\begin{tabular}{|c|c|c|c|c|c|c|}
\hline & Species & $\begin{array}{l}\text { Physical size } \\
(\mathrm{Mb})\end{array}$ & $\begin{array}{c}\text { Genetic length }(\mathrm{cM}) \\
\text { (MAPMAKER estimates) }\end{array}$ & $\begin{array}{c}\text { Chromosome } \\
\text { number }\end{array}$ & $\begin{array}{l}\text { Mean genetic size per } \\
\text { chromosome }(\mathrm{cM})\end{array}$ & $\begin{array}{c}\text { Physical/genetic size ratio } \\
(\mathrm{Mb} / \mathrm{cM})\end{array}$ \\
\hline 1 & Arabidopsis thaliana & $150^{[4]}$ & $675^{[50]}$ & 5 & 135 & 0.22 \\
\hline 2 & Prunus persica & $300^{[4]}$ & $712^{[20]}$ & 8 & 90 & 0.42 \\
\hline 3 & Oryza sativa & $450^{[4]}$ & $1490^{[2]}$ & 12 & 125 & 0.3 \\
\hline 4 & Populus deltoides & $550^{[4]}$ & $2300^{[16]}$ & 19 & 121 & 0.23 \\
\hline 5 & Eucalyptus grandis & $600^{[4]}$ & $1370^{[64]}$ & 11 & 125 & 0.43 \\
\hline 8 & Lycopersicon esculentum & $980^{[4]}$ & $1280^{[57]}$ & 12 & 107 & 0.76 \\
\hline 9 & Solanum tuberosum & $1540^{[4]}$ & $1120^{[58]}$ & 12 & 93 & 1.37 \\
\hline 10 & Zea mays & $2500^{[4]}$ & $1860^{[13]}$ & 10 & 186 & 1.34 \\
\hline 11 & Lactuca sativa & $2730^{[4]}$ & $1950^{[27]}$ & 9 & 217 & 1.4 \\
\hline 12 & Triticum tauschii & $4200^{[7]}$ & $1330^{[38]}$ & 7 & 190 & 3.15 \\
\hline
\end{tabular}



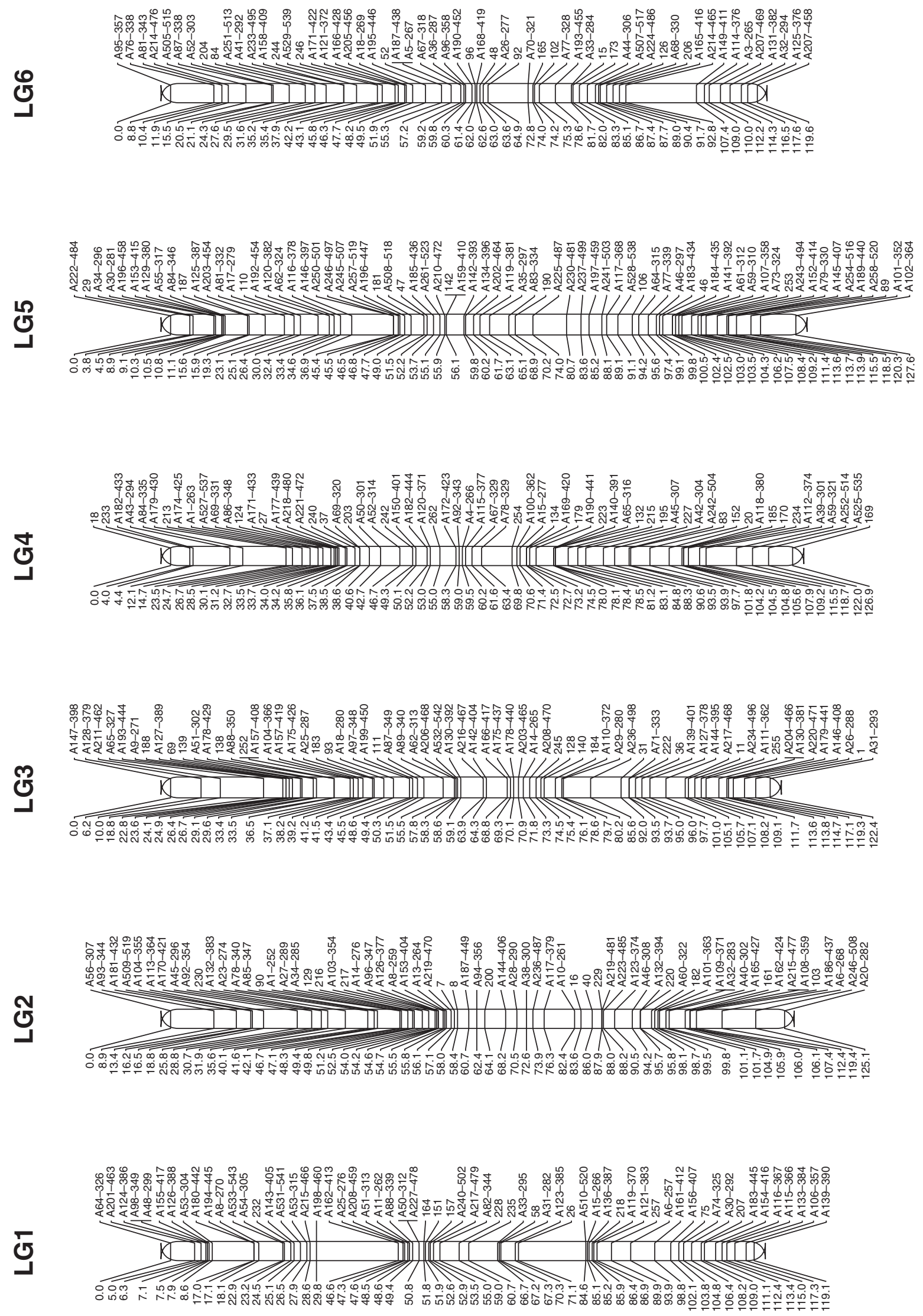


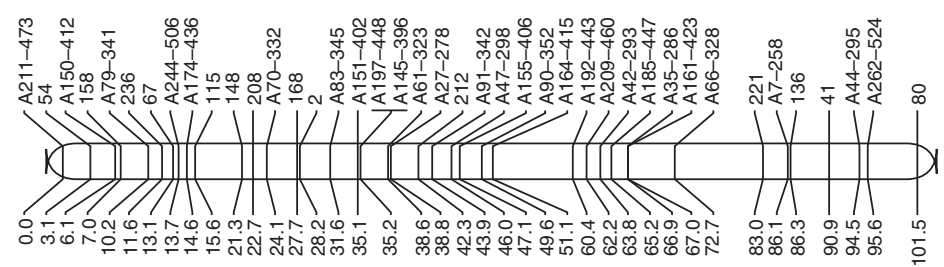

$\bar{\Xi}$

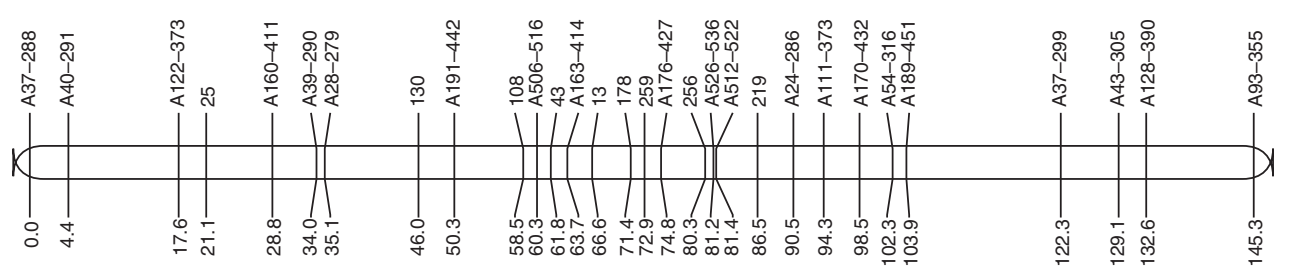

ङ
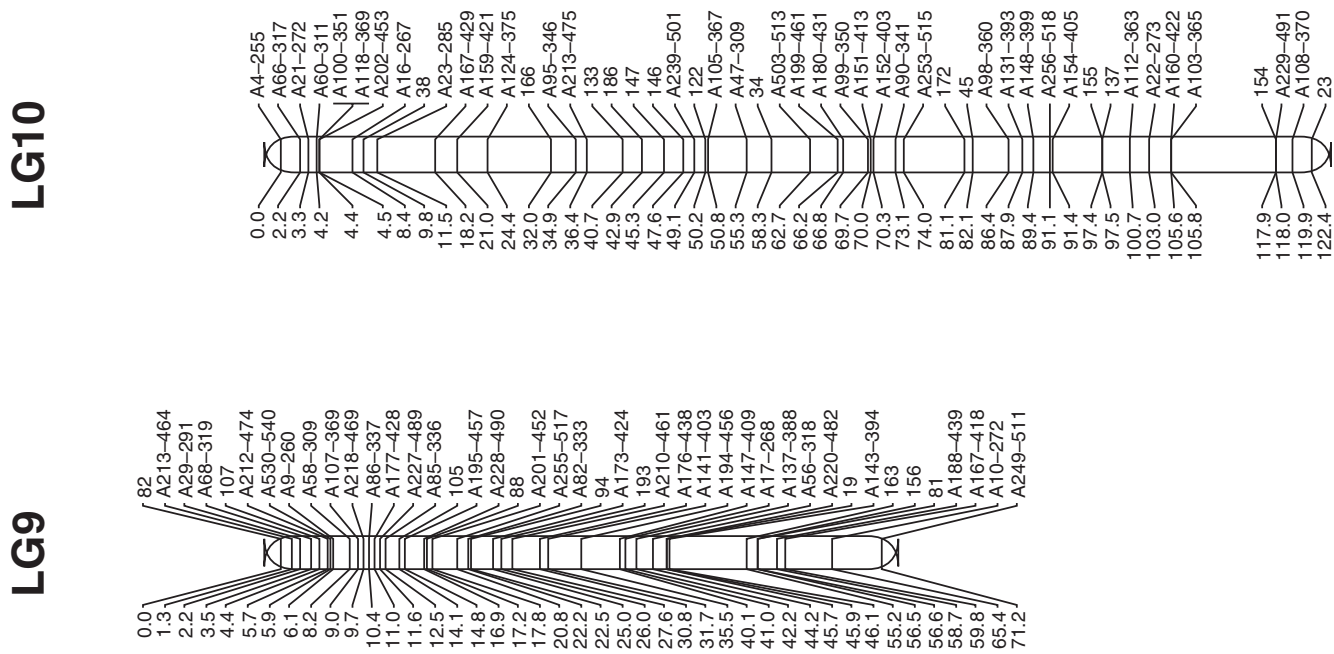

ฐ
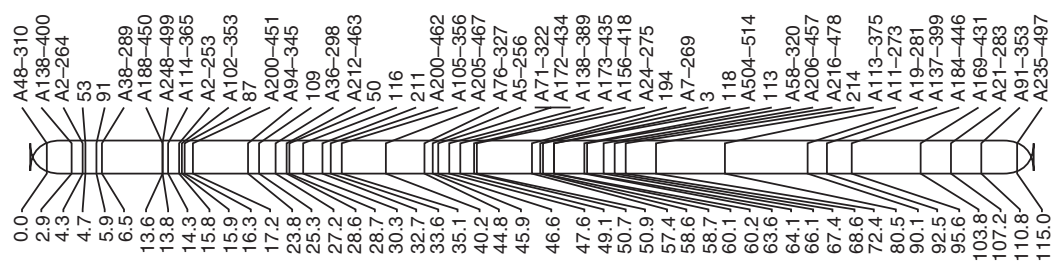

$\Xi$

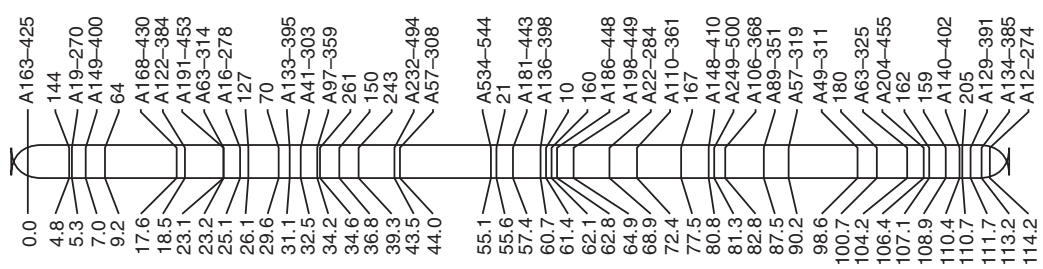




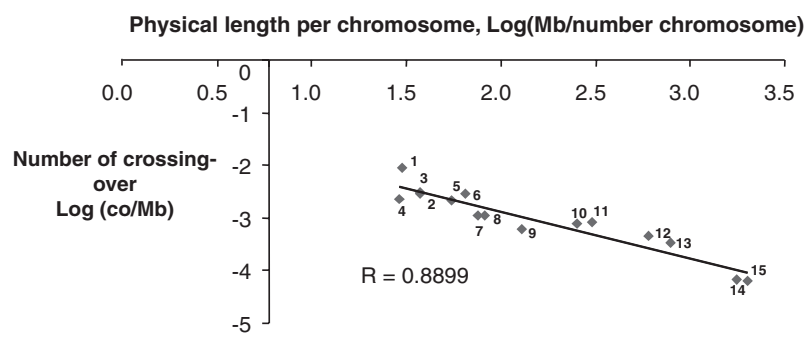

Figure 4. Relationship between the number of crossing-over and the mean physical size per chromosome in 15 plant species. The correspondence between the number and the 15 species is presented in table III.

species (table III), species with small chromosomes will present a larger amount of recombination per unit of physical size.

\section{PERSPECTIVES}

The new maritime pine genetic map provides a very useful tool for further genetic analysis. First, this map will serve as a framework to locate comparative anchor tags for comparative genomics. Although AFLP markers have been shown to be poorly transferable between pine species, orthologous markers such as RFLPs, ESTPs [61] or SSRs can be used as anchor-points between the different maps already available for conifer species. ESTs which have been mapped in Pinus taeda $[26,61]$ and ESTs from $P$. pinaster cDNA libraries are currently being located in the AFLP map of maritime pine as part of the Conifer Comparative Genome Project (CCGP; http://dendrome.ucdavis.edu/Synteny/index.html). The aim of CCGP is to compare conifer genetic maps with the P. taeda reference map by providing orthologous markers. A hierarchical approach based on different PCR-based methods is used to detect polymorphism in ESTs: PCR fragment length and conformation in denaturing or non-denaturing gel conditions (SSCP [47] and DGGE [60]) are first used because of their low or medium cost and time efficiency. More powerful methods such as point mutation detection by systematic sequencing, or such as the prospecting of variation in the non-coding regions flanking the ESTs [12], will also be used to increase polymorphism rate.

As for the "intraspecific mapping comparison", some of the AFLP markers will be transferable between pedigrees of maritime pine, but to compare maps constructed based on different genetic backgrounds (e.g.: using experimental design such as factorial and diallel), SSRs will be the marker of choice. Their multiallelic nature will also allow tagging multiple alleles at QTLs. Development of a battery of SSRs for maritime pine is therefore a priority.

Secondly, genomic regions controlling adaptive and economically important traits are currently being studied in maritime pine. These include QTLs for growth, wood quality, end-uses properties and water use efficiency [9]. These studies are based on a skeleton map based on evenly spaced AFLP markers genotyped on the whole mapping pedigree (202 full-sibs; Pot, unpublished). The ESTs described in the previous paragraph will also provide positional candidate genes, i.e. whose position coincides with mapped QTLs. However, because of the high physical/genetic size ratio in conifers, it will be of great importance to find the actual genes underlying QTLs of interest, before any attempt of using this information in Marker-Assisted Breeding Program. The location of candidate genes will also contribute to the establishment of a "functional" genetic map.

In an integrative study, it will be essential to use the same markers (ESTs) for comparative mapping and the candidate gene approach, in order to validate the candidate gene-QTL co-locations between phylogenetically related species [39].

Acknowledgements: The authors are grateful to the reviewers for comments on the manuscript. This work was supported by funding from the European Union (ANACONGEN, BI04-CT97-2125) and the French Ministry of Research (BIOTECH, décision $\mathrm{n}^{\circ}$ 98C0204).

\section{REFERENCES}

[1] Adams W.T., Joly R.J., Linkage relationships among twelve allozyme loci in loblolly pine, J. Hered. 71 (1980) 199-202.

[2] Ahn S., Tanskley S., Comparative linkage maps of the rice and maize genomes, Proc. Natl. Acad. Sci. USA 90 (1993) 7980-7984.

[3] Arcade A., Anselin F., Faivre Rampant P., Lesage M.C., Laurans F., Paques L.E., Prat D., Application of AFLP, RAPD and ISSR markers to genetic mapping of European larch and Japanese larch, Theor. Appl. Genet. 100 (2000) 299-307.

[4] Arumuganathan K., Earle E.D., Nuclear DNA content of some important plant species, Plant Mol. Biol. Rep. 9 (1991) 208-218.

[5] Baradat P., Pastuszka P., Le pin maritime, in: Gallais A., Bannerot H. (Éds.), Amélioration des espèces végétales cultivées, INRA édition, Paris, 1992, pp. 695-709.

[6] Barreneche T., Bodénès C., Lexer C., Trontin J.F., Fluchs S., Streiff R., Plomion C., Roussel G., Steinkellner H., Burg K., Favre J.-M., Glossl J., Kremer A., A genetic linkage map of Quercus robur (Pedunculate oak) based on RAPD, SCAR, microsatellite, isozyme and rDNA markers, Theor. Appl. Genet. 97 (1998) 1090-1103.

[7] Bennett M.D., Smith J.B., Nuclear DNA amount in angiosperms, Phil. Trans. R. Soc. Lond. B 274 (1976) 227-274.

[8] Botstein D., White R., Skolnick M., Davis R., Construction of genetic linkage map in man using restriction fragment length polymorphism, Am. J. Hum. Genet. 32 (1980) 641-656.

[9] Brendel O., Pot D., Plomion C., Rozenberg P., Guelh J.-M., Genetic parameters and QTL analysis of $\delta^{13} \mathrm{C}$ and ring width in maritime pine, Plant Cell Env. 25 (2002) 945-953.

[10] Byrne M., Murell J.C., Allen B., Moran G.F., An integrated genetic linkage map for eucalypts using RFLP, RAPD and isozyme markers, Theor. Appl. Genet. 91 (1995) 869-875.

[11] Carlson J.E., Tulsieram L.K., Glaubitz J.C., Luk V.W.K., Kauffeld C., Rutledge R., Segregation of random amplified DNA markers in F1 progeny of conifers, Theor. Appl. Genet. 83 (1991) 194-200.

[12] Cato S.A., Gardner R.C., Kent J., Richardson T.E., A rapid PCR-based method for genetically mapping ESTs, Theor. Appl. Genet. 102 (2001) 296-306. 
[13] Causse M., Santoni S., Damerval C., Maurive A., Charcosset A., Deatrick J., de Vienne D., A composite map of expressed sequences in maize, Genome 39 (1996) 418-432.

[14] Cervera M.T., Plomion C., Malpica C., Molecular markers and genome mapping in woody plants, in: Jain S.M., Minocha S.C. (Eds.), Molecular Biology of Woody Plants, Vol. I, 2000, pp. 375-394.

[15] Cervera M.T., Remington D., Frigerio J.M., Storme V., Ivens B., Boerjan W., Plomion C., Improved AFLP analysis of tree species, Can. J. For. Res. 30 (2000) 1608-1616.

[16] Cervera M.T., Storme V., Ivens B., Gusmao J., Liu B.H., Hostyn V., Van Slycken J., Van Montagu M., Boerjan W., Dense genetic linkage maps of three populus species (Populus deltoides, $P$. nigra and P. trichocarpa) based on AFLP and microsatellite markers, Genetics 158 (2001) 787-809.

[17] Costa P., Durel C.E., Time trends in genetic control over height and diameter in maritime pine, Can. J. For. Res. 26 (1996) 1209-1217.

[18] Costa P., Pot D., Dubos C., Frigerio J.-M., Pionneau C., Bodénès C., Bertocchi E., Cervera M.T., Remington D.L., Plomion C., A genetic map of maritime pine based on AFLP, RAPD and protein markers, Theor. Appl. Genet. 100 (2000) 39-48.

[19] Devey M.E., Bell J.C., Smith D.N., Neale D.B., Moran G.F., A genetic map for Pinus radiata based on RFLP, RAPD and microsatellite markers, Theor. Appl. Genet. 92 (1996) 673-679.

[20] Dirlewanger E., Pronier V., Parvery C., Rothan C., Guye A., Monet R., Genetic linkage map of peach [Prunus persica (L.) Batsch] using morphological and molecular markers, Theor. Appl. Genet. 97 (1998) 888-895.

[21] Doyle J.J., Doyle J.L., Isolation of plant DNA from fresh tissue, Focus 12 (1990) 13-15.

[22] Echt C.S., Nelson C.D., Linkage mapping and genome length in eastern white pine (Pinus strobus L.), Theor. Appl. Genet. 94 (1997) 1031-1037.

[23] Galbraith D., Harkins K., Maddox J., Ayres N., Sharma D., Firoozabady E., Rapid flow cytometric analysis of the cell cycle in intact plant tissues, Science 220 (1983) 1049-1051.

[24] Grattapaglia D., Sederoff R., Genetic linkage maps of Eucalyptus grandis and Eucalyptus europhylla using a pseudo testcross: mapping strategy and RAPD markers, Genetics 137 (1994) 1121-1137.

[25] Han T.H., van Eck H.J., de Jeu M.J., Jacobsen E., Optimization of AFLP fingerprinting of organisms with large-sized genome: a study on Alstoemeria spp, Theor. Appl. Genet. 98 (1999) 465-471.

[26] Harry D.E., Temesgen B., Neale D.B., Codominant PCR-based markers for Pinus taeda developed from mapped cDNA clones, Theor. Appl. Genet. 97 (1998) 327-336.

[27] Hulbert S.H., Hott T.W., Legg E.J., Lincoln S.E., Lander E.S., Michelmore R.W., Genetic analysis of the fungus, Bremia lactucae, using restriction length polymorphism, Genetics 120 (1988) 947-958.

[28] Jacobs J.M.E., van Eck H.J., Arens P., Verkerk-Bakker B., te Lintel Hekkert B., Bastiaansen H.J.M., El-Karbotly A., Pereira A., Jacobsen E., Stiekema W.J., A genetic map of potato (Solanum tuberosum) integrating molecular markers, including transposons and classical markers, Theor. Appl. Genet. 91 (1995) 239-300.

[29] Kleinhofs A., Kilian A., Saghai Maroof M.A., Biyashev R.M., Hayes P., Chen F.Q., Lapitan N., Fenwick A., Blake T.K., Kanazin V., Ananiev E., Dahleen L., Kudrna D., Bollinger J., Knapp S.J., Liu B., Sorrells M., Heun M., Franckowiack J.D., Hoffmann D., Skadsen R., Steffenson B.J., A molecular, isozyme and morphological map of barley (Hordeum vulgare) genome, Theor. Appl. Genet. 86 (1993) 705-712.

[30] Kohler B., Guttenberger H., Borzan Z.G., C-banding pattern of the chromosomes in the macrogametophyte of Norway spruce, Silvae Genet. 45 (1996) 16-21.

[31] Kremer A., Lascoux D.M., Genetic architecture of height growth in maritime pine (Pinus pinaster Ait.), Silvae Genet. 37 (1988) 1-8.

[32] Kremer A., Lascoux M., Nguyen A., Morphogenetic subdivision of height growth and early selection in maritime pine, Proceedings of the 21st Southern Forest Tree Improvement Conference, 1991, pp. 203-221.

[33] Kubisiak T.L., Nelson C.D., Nance W.L., Stine M., RAPD linkage mapping in a longleaf pine $\times$ slash pine F1 family, Theor. Appl. Genet. 90 (1996) 1110-1127.
[34] Lander E.S., Green P., Abrahamson J., Barlow A., Daly M.J., Lincoln S.E., Newberg L., MAPMAKER: an interactive computer package for constructing primary genetic maps of experimental and natural populations, Genomics 1 (1987) 174-181.

[35] Marie D., Brown S., A cytometric exercise in plant DNA histograms, with 2C values for 70 species, Bio. Cell. 78 (1993) 41-51.

[36] Marques C.M., Araujo J.A., Ferreira J.G., Whetten R., O’Malley D.M., Liu B.H., Sederoff R., AFLP genetic maps of Eucalyptus globulus and E. tereticornis, Theor. Appl. Genet. 96 (1998) 727-737.

[37] Murray B., Nuclear DNA amounts in gymnosperms, Ann. Bot. 83 (1998) 3-15.

[38] Namuth D.M., Lapitan N.L.V., Gill K.S., Gill B.S., Comparative RFLP mapping of Hordeum vulgare and Triticum tauschii, Theor. Appl. Genet. 89 (1994) 865-872.

[39] Neale D.B., Sewell M.M., Brown G.R., Molecular dissection of the quantitative inheritance of wood property traits in loblolly pine, Ann. For. Sci. 59 (2002) 595-605.

[40] O’Brien I., Smith D., Gardner R., Murray B., Flow cytometric determination of genome size in Pinus, Plant Sci. 115 (1996) 91-99.

[41] Ohri D., Khoshoo T.N., Genome size in gymnosperms, Pl. Syst. Evol. 153 (1986) 119-132.

[42] O’Malley D.M., Whetten R., Moleculars markers and forest trees, in: Caetano-Anollès G., Gresshoff P.M. (Eds.), DNA markers: Protocols, Applications and Overviews, 1997, pp. 237-257.

[43] Paglia G.P., Olivieri A.M., Morgante M., Towards second-generation STS (sequence-tagged sites) linkage maps in conifers: a genetic map of Norway spruce (Picea abies K.), Mol. Gen. Genet. 258 (1998) 466-478.

[44] Plomion C., Bahrman N., Durel C.E., O’Malley D.M., Genomic mapping in Pinus pinaster (maritime pine) using RAPD and protein markers, Heredity 74 (1995) 661-668.

[45] Plomion C., Durel C.E., Estimation of the average effects of specific alleles detected by the pseudo-testcross QTL mapping strategy, Genet. Sel. Evol. 28 (1996) 223-235.

[46] Plomion C., Durel C.E., O’Malley D.M., Genetic dissection of height in maritime pine seedlings raised under accelerated growth conditions, Theor. Appl. Genet. 93 (1996) 849-858.

[47] Plomion C., Hurme P., Frigerio J.-M., Ridolfi M., Pot D., Pionneau C., Avila C., Gallardo F., David H., Neutelings G., Campbell M., Canovas F.M., Savolainen O., Bodénès C., Kremer A., Developing SSCP markers in two Pinus species, Mol. Breed. 5 (1999) 21-31.

[48] Pot D., Chantre G., Rozenberg P., Rodrigues J.C., Jones G.L., Pereira H., Hannrup B., Cahalan C., Plomion C., Genetic control of pulp and timber properties in maritime pine (Pinus pinaster Ait.), Ann. For. Sci. 59 (2002) 563-575.

[49] Qi X., Stam P., Lindhout P., Comparison and integration of four barley genetic maps, Genome 39 (1996) 379-394.

[50] Reiter R.S., Williams J., Feldman K., Rafalski J.A., Tingey S.V., Scolnik P.A., Global and local genome mapping in Arabidopsis thaliana recombinant inbred lines and random amplified polymorphic DNAs, Proc. Natl. Acad. Sci. USA 89 (1992) 1477-1481.

[51] Remington D.L., Whetten R.W., Liu B.H., O’Malley D.M., Construction of an AFLP genetic map with nearly complete genome coverage in Pinus taeda, Theor. Appl. Genet. 98 (1999) 1279-1292.

[52] Ritter E., Gebhardt C., Salamini F., Estimation of recombination frequencies and construction of RFLP linkage maps in plants from crosses between heterozygous parents, Genetics 125 (1990) 645-654.

[53] Ritter E., Aragonés A., Markussen T., Acheré V., Espinel S., Fladung M., Wrobel S., Faivre-Rampant P., Jeandroz S., Favre J.-M., Towards construction of an ultra high density linkage map for Pinus pinaster, Ann. For. Sci. 59 (2002) 637-643.

[54] Sewell M.M., Sherman B.K., Neale D.B., A consensus map for loblolly Pine (Pinus taeda L.). I. Construction and integration of individual linkage maps from two outbred three-generation pedigrees, Genetics 151 (1999) $321-330$.

[55] Sewell M.M., Bassoni D.L., Megraw R.A., Wheeler N.C., Neale D.B., Identification of QTLs influencing wood property traits in loblolly pine 
(Pinus taeda L.). I. Physical wood properties, Theor. Appl. Genet. 101 (2000) 1273-1281.

[56] Song K.M., Suzuki J.Y., Slocum M.K., Williams P.H., Osnorn T.C., A linkage of Brassica rapa (syn. Campestris) based on restriction fragment length polymorphism loci, Theor. Appl. Genet. 82 (1991) 296-304.

[57] Stam P., Construction of integrated linkage maps by means of a new computer package: JOINMAP, Plant J. 3 (1993) 739-744.

[58] Tanksley S.D., Ganal M.W., Prince J.P., de Vicente M.C., Bonerbiale M.W., Broun P., Fulton T.M., Giovannoni J.J., Grandillo S., Martin G.B., Messeguer R., Miller J.C., Miller L., Paterson A.H., Pineda O., Roder M.S., Wing R.A., Wu W., Young N.D., High dendity molecular linkage maps of the tomato and potato genomes, Genetics 132 (1992) 1141-1160.

[59] Tanksley S.D., Mapping Polygenes, Ann. Rev. Genet. 27 (1993) 205-233.

[60] Temesgen B., Neale D.B., Harry D.E., Use of haploid mixtures and heteroduplex analysis enhance polymorphism revealed by Denaturing Gradient Gel Electrophoresis, BioTechniques 20 (2000) 114-122.

[61] Temesgen B., Brown G.R., Harry D.E., Kinlaw C.S., Sewell M.M., Neale D.B., Genetic mapping of expressed sequence tag polymorphism (ESTP) markers in loblolly pine (Pinus taeda L.), Theor. Appl. Genet. 102 (2001) 664-675.
[62] Travis S.E., Ritland K., Whitman T.G., Keim P., A genetic linkage map of Pinyon pine (Pinus edulis) based on amplified fragment length polymorphism, Theor. Appl. Genet. 97 (1998) 871-880.

[63] Tulsieram L.K., Glaubitz J.C., Kiss G., Carlson J.E., Single tree genetic linkage analysis in conifers using haploid DNA from megagametophytes, BioTechnology 10 (1992) 686-690.

[64] Verhaegen D., Plomion C., Genetic mapping in Eucalyptus urophylla and E. grandis using RAPD markers, Genome 39 (1996) 1051-1061.

[65] Voorips R.E., Mapchart version 2.0: Windows software for the graphical presentation of linkage maps and QTLs, Plant Research International, Wageningen, The Netherlands, 2001.

[66] Vos P., Hogers R., Bleeker M., Reijans M., van der Lee T., Hornes M., Frijters A., Pot J., Pelemam J., Kuiper M., Zabeau M., AFLP: a new technique for DNA fingerprinting, Nucleic Acids Res. 23 (1995) 4407-4414.

[67] Wakamiya I., Newton R. Johnston J.S., Price H.J., Genome size and environmental factors in the genus Pinus, Am. J. Bot. 80 (1993) 1235-1241.

[68] Williams J.G.K., Kubelik A.R., Livak K.J., Rafalski J.A., Tingey S.V., DNA polymorphisms amplified by arbitrary primers are useful as genetic markers, Nucleic Acids Res. 18 (1990) 6531-6535.

To access this journal online: www.edpsciences.org 